\title{
Baza biblioteczna KOHA - krok ku usprawnieniu informacji naukowej w archiwach państwowych
}

Archiwa państwowe, poza realizacją swoich statutowych zadań wynikających z Ustawy o narodowym zasobie archiwalnym i archiwach, gromadzą także zbiory biblioteczne. Początki biblioteki Archiwum Narodowego w Krakowie sięgają końca XIX w. (pierwszy inwentarz założono ok. 1893 r.). O właściwej bibliotece można jednak mówić dopiero od 1952 r., kiedy to z połączenia Archiwum Aktów Dawnych Miasta Krakowa i Archiwum Państwowego w Krakowie powstało Wojewódzkie Archiwum Państwowe w Krakowie. Obecnie gromadzenie księgozbioru odbywa się statutowo w ramach Oddziału III akt miasta Krakowa, samorządu terytorialnego, wyznaniowych, szkół i organizacji społecznych. Liczy on już ponad 30 tys. tytułów. Mniej zasobne biblioteki funkcjonują również w pozostałych krakowskich oraz zamiejscowych oddziałach Archiwum. Zbiory udostępnia się użytkownikom stacjonarnie w czytelniach.

Ze względu na specyfikę zgromadzonych publikacji księgozbiór Archiwum można określić mianem biblioteki specjalnej, gdzie zbiory zgrupowane są według określonej dziedziny oraz adresowane do wybranego grona odbiorców. Większość stanowią w nim pozycje związane z archiwistyką i naukami pomocniczymi historii. Warsztat archiwisty wspomagają również opracowania ogólne, takie jak słowniki, informatory, bibliografie, a także wydawnictwa źródłowe czy druki urzędowe (dzienniki ustaw, szematyzmy galicyjskie, rozporządzenia). Licznie reprezentowane są publikacje dotyczące regionu krakowskiego: statuty stowarzyszeń, kalendarze, wydawnictwa naukowe i popularnonaukowe, pamiętniki, biografie. Wśród posiadanych przez Archiwum książek nie brak różnego typu nabytków, które na przestrzeni lat trafiały w postaci darów od różnych instytucji, użytkowników zasobu, pracowników etc. Można więc znaleźć publikacje z zakresu etnografii, socjologii, historii literatury polskiej, czy nawet informatyki.

Do 2018 r. informacji o zbiorach dostarczał nieuzupełniany od lat katalog kartkowy oraz „Biblioteka” - baza danych utworzona w 2014 r. w programie Access. W związku z potrzebą ujednolicenia systemu informacji naukowej w archiwach, decyzją Naczelnego Dyrektora Archiwów Państwowych, jako Centralny System Biblioteczny dla sieci archiwalnej w Polsce wprowadzono system KOHA. Do realizacji projektu w pierwszej kolejności przystąpiły: Archiwum Narodowe w Krakowie, Archiwum Główne Akt Dawnych oraz archiwa państwowe z Katowic, Lublina, Opola i Przemyśla. W związku z pracami wdrożeniowymi odbyło się wiele szkoleń dotyczących zagadnienia katalogowania w formacie MARC21, obsługi systemu oraz zasad ewidencji materiałów bibliotecznych (szkolenie przeprowadzone przez pracowników Biblioteki Narodowej). Podjęto również bierną współpracę z Narodowym Uniwersalnym Katalogiem Centralnym (NUKAT), dzięki czemu archiwa państwowe mają możliwość pobierania danych, a informacja o dostępności publikacji wraz z odnośnikiem pojawia się na stronie NUKAT. 
KOHA jest zintegrowanym systemem bibliotecznym opartym na zasadzie open source, czyli wolnego oprogramowania. Program powstał pod koniec 1999 r. z inicjatywy nowozelandzkiego Horowhenua Library Trust. Bezpłatne użytkowanie odbywa się na zasadzie licencji. Jego zaletą jest opcja modyfikacji dostosowana do konkretnych potrzeb użytkowników. Wbudowany protokół pobierania danych Z39.50 ułatwia pozyskiwanie gotowych rekordów dla pozycji bibliotecznych. Istnieje również możliwość katalogowania poprzez samodzielne tworzenie opisów publikacji. KOHA pozwala także na prowadzenie obsługi czytelników (rejestr wypożyczeń i zwrotów), tworzenie ksiąg inwentarzowych w wersji elektronicznej, wprowadzanie akcesji czy drukowanie etykiet (kodów kreskowych).

W 2018 r. baza została uzupełniona o 4675 pozycji. Mimo że pozostało jeszcze wiele pracy nad wprowadzaniem rekordów do tego dostępnego online katalogu, systematycznie uzupełniana KOHA nie tylko usprawni proces informacji naukowej, ale także umożliwi chociaż częściową inwentaryzację zasobu bibliotecznego przed planowaną przeprowadzką do nowej siedziby Archiwum Narodowego.

Karolina Zięba Archiwum Narodowe w Krakowie 